\title{
Religion and Legal Spaces - In Gods we Trust; in the Church, we Trust, but need to Verify
}

\author{
Dominic McGoldrick*
}

Keywords: religion - freedom of religion - churches - religious autonomy - employment ministerial exception - United States Constitution First Amendment - Article 9 European Convention on Human Rights - legal spaces - Hosanna-Tabor Evangelical Lutheran Church and School v Equal Employment Opportunity Commission - Fernández Martínez v Spain The President of the Methodist Conference v Preston (formerly Moore)

\section{Introduction}

The relationship between religion and law is inherently unstable and ambivalent. ${ }^{1}$ Religion professes faith in God's (or some other higher being's) law rather than man's. Religions want the protection of the law for their manifestations and beliefs and their social and institutional existence. However, they resist any incursion by the laws into areas where their beliefs and decisions are assessed for compatibility with national or international secular norms. Particular difficulties are created if courts try to assess religious doctrines and beliefs or subject them to secular standards of rationality, proportionality and non-discrimination. ${ }^{2}$ Thus religions are always in a troublesome dialectical relationship with the law. Major judicial decisions can signal the ways in which that relationship is evolving. ${ }^{3}$ In particular they can do so by revealing whether the law makes spaces to account for the forces of religion and how those spaces operate and interact with other forces.

Nature may abhor a vacuum (horror vacui $)^{4}$ but a vacuum can exist because of the operation of other forces, such as gravity. Abhorrence expresses the idea that empty or unfilled spaces are unnatural as they go against the laws of nature and physics. By analogy it can be argued that the rule of law similarly abhors empty or unfilled legal spaces or black holes as they are unnatural as they go against the rule of law. ${ }^{5}$ For a lawyer the rule of law exerts a magnetic sense in as much as it claims that no legal powers should be uncontrollable. ${ }^{6}$ Along with the normative force of human rights, this partly explains the increasingly limited scope of doctrines such as non-justiciability. ${ }^{7}$ One of the forces which can create empty legal spaces is that of religion. This article compares and contrasts three cases in three different legal arenas

\footnotetext{
" Professor of International Human Rights Law, Human Rights Law Centre, University of Nottingham [dominic.mcgoldrick@ nottingham.ac.uk] I am grateful to Professor Lucy Vickers, Oxford Brookes University, for her comments on a draft. Responsibility for the view expressed is mine alone.

${ }^{1}$ See Rivers, The Law of Organized Religions: Between Establishment and Secularism (Oxford: Oxford University Press, 2010); Sandberg, Law and Religion (Cambridge: Cambridge University Press, 2011).

${ }^{2}$ See Edge, 'Determining Religion in English Courts' (2012) 1 Oxford Journal of Law and Religion xx; Sandberg, 'The Adventures of Religious Freedom: Do Judges Understand Religion?' 21 March 2012, available at: http://ssrn.com/abstract=2032643 [last accessed 1 August 2012]

${ }^{3}$ So too, of course, can legislative developments.

${ }^{4}$ The saying is commonly attributed to Aristotle.

${ }^{5}$ See Steyn, 'Guantanamo Bay - The Legal Black Hole' (2004) 53 International and Comparative Law Quarterly 1.

${ }^{6}$ See Bingham, The Rule of Law (London: Allen Lane, 2010).

${ }^{7}$ See McGoldrick, 'The Boundaries of Justiciability' (2010) 59 International and Comparative Law Quarterly 981. Though for a recent application of the non-justiciability principle because it would have required an English court to adjudicate on an issue of succession by reference to Sikh religious beliefs and practices see Mohinder Singh Khaira and Others v. Daljit Singh Shergill and Others, (2012) EWCA Civ 983 (17 July 2012).
} 
in which this force has been at work. ${ }^{8}$ First, the unanimous decision of the US Supreme Court in Hosanna-Tabor Evangelical Lutheran Church and School v Equal Employment Opportunity Commission ' ('Hosanna-Tabor') in which it was held that the Establishment and Free Exercise Clauses of the First Amendment of the US Constitution barred suits brought on behalf of Ministers against their churches claiming termination in violation of employment discrimination laws. Second, the majority decision of the European Court of Human Rights (ECtHR) in Fernández Martínez v Spain ${ }^{10}$ ('Fernández Martínez') will be considered. In this case the ECtHR held that a decision not to renew the contract of a priest, who was married with five children, to teach Catholic religion and morals, following the publication of an article disclosing his membership of the 'Movement for Optional Celibacy', did not violate his right to private life under Article 8 of the European Convention on Human Rights (ECHR). Thirdly, the decision of the Court of Appeal of England and Wales in The President of the Methodist Conference v Preston (formerly Moore) ${ }^{11}$ ('Preston') that a Minister in a Methodist Church was an 'employee' and could, therefore, bring a claim for unfair dismissal.

\section{Hosanna-Tabor}

Hosanna-Tabor Evangelical Lutheran Church and School was a member congregation of the Lutheran Church-Missouri Synod. ${ }^{12}$ The Synod classified its school teachers into two categories: 'called' and 'lay'. 'Called' teachers are regarded as having been called to their vocation by God. To be eligible to be considered 'called', a teacher must complete certain academic requirements, including a course of theological study. Once 'called', a teacher receives the formal title 'Minister of Religion, Commissioned'. In contrast, 'Lay' teachers are not required to be trained by the Synod or even to be Lutheran. Although lay and called teachers at Hosanna-Tabor generally performed the same duties, lay teachers were hired only when called teachers were unavailable. Hosanna-Tabor asked Cheryl Perich ('P') to become a called teacher and she accepted. ${ }^{13} \mathrm{P}$ taught secular subjects. In addition she taught a religion class, led her students in daily prayer and devotional exercises, and took her students to a weekly schoolwide chapel service. P led the chapel service herself about twice a year. P developed narcolepsy and began the 2004-2005 school year on disability leave. In January 2005, she notified the school principal that she would be able to report to work in February. The principal responded that the school had already contracted a lay teacher to fill P's position for the remainder of the school year. The principal also expressed concern that $\mathrm{P}$ was not yet ready to return to the classroom. The congregation subsequently offered to pay a portion of P's health insurance premiums in exchange for her resignation as a called teacher. P refused to resign. In February 2005, P presented herself at the school and refused to leave until she received written documentation that she had reported to work. The principal later called $\mathrm{P}$ and told her that it was likely she would be fired. P responded that she had spoken with an attorney and intended to assert her legal rights. In a subsequent letter, the chairman of the school board advised $\mathrm{P}$ that the congregation would consider whether to rescind her call at its next meeting. As grounds for termination, the letter cited P's 'insubordination and disruptive behavior', as well as the damage she had done to her 'working relationship' with the school by 'threatening to take legal

\footnotetext{
${ }^{8}$ See also Evans and Hood, 'Religious Autonomy and Labour Law: A Comparison of the Jurisprudence of the US and the European Court of Human Rights' (2012) 1 Oxford Journal of Law and Religion 91.

9131 SC 1783 (2011). The Opinion was delivered by Robert CJ.

${ }^{10}$ Application no 56030/07, Merits, 15 May 2012. [The judgment is available only in French.]

${ }^{11}$ [2011] EWCA Civ 1581; [2012] 2 All ER 934.

12 See 'Hosanna -Tabor Lutheran Church and Early Childhood Centre': http://www.hosannatabor.org/ [last accessed 1 August 2012].

13 'Called teachers' were usually hired on an open-ended basis by the voting members of the church congregation.
} 
action'. The congregation voted to rescind P's call, and Hosanna-Tabor sent her a letter of termination. P filed a charge with the Equal Employment Opportunity Commission (EEOC), claiming that her employment had been terminated in violation of the Americans with Disabilities Act (ADA). ${ }^{14}$ The EEOC commenced a suit against Hosanna-Tabor, alleging that $\mathrm{P}$ had been fired in retaliation for threatening to file an ADA lawsuit. $\mathrm{P}$ intervened in the litigation. Invoking what is known as the 'ministerial exception', Hosanna-Tabor argued that the suit was barred by the First Amendment because the claims concerned the employment relationship between a religious institution and one of its ministers. According to the Church, $\mathrm{P}$ was a minister, and she had been fired for a religious reason - namely, that her threat to sue the Church violated the Synod's belief that Christians should resolve their disputes internally. The District Court agreed and granted summary judgment in Hosanna Tabor's favour. The Sixth Circuit vacated and remanded. ${ }^{15}$ It recognised the existence of a ministerial exception rooted in the First Amendment, but concluded that P did not qualify as a 'minister' under the exception.

In Hosanna-Tabor the Supreme Court (SC) reversed the opinion of the Appeals Court. It recognised, for the first time, ${ }^{16}$ a 'Ministerial Exception' that precluded application of such legislation to claims concerning the employment relationship between a religious institution and its ministers. The exception was based on the First Amendment, which provides, in part, that 'Congress shall make no law respecting an establishment of religion, or prohibiting the free exercise thereof'. In the SC's view, both the Establishment Clause and the Free Exercise Clause $\mathrm{c}$ barred the government from interfering with the decision of a religious group to fire one of its ministers. It considered that the Establishment Clause prevented the Government from appointing ministers and the Free Exercise Clause prevented it from interfering with the freedom of religious groups to select their own. ${ }^{17}$ It found support for this interpretation in events in the early 19th century involving James Madison, 'the leading architect of the religion clauses of the First Amendment', ${ }^{18}$ and in analogous jurisprudence concerning disputes over church property. ${ }^{19}$ In the latter jurisprudence the SC had made clear that it would not adjudicate on ecclesiastical matters such as the selection of the clergy. ${ }^{20}$ It would not even inquire into whether the church had followed its own procedures. ${ }^{21}$ In its central finding in Hosanna-Tabor the SC held that,

Requiring a church to accept or retain an unwanted minister, or punishing a church for failing to do so, intrudes upon more than a mere employment decision. Such action interferes with the internal governance of the church, depriving the church of control over the selection of those who will personify its beliefs. By imposing an unwanted minister, the state infringes the Free Exercise Clause, which protects a religious group's right to shape its own faith and mission through its

\footnotetext{
${ }^{14}$ See Americans With Disabilities Act Of 1990, as Amended, United States Code, Title 42, chapter 126, section 12101 and Title 47, chapter 5, available at

http://www.ada.gov/pubs/adastatute08.htm [last accessed 1 August 2012]

${ }^{15}$ Hosanna-Tabor Evangelical Lutheran Church and School v Equal Employment Opportunity Commission 597 F.3d 769 (6th Cir 2010).

${ }^{16}$ Various US Courts of Appeal had recognised the doctrine since McClure v Salvation Army 460 F.2d 553 (5th Cir 1972) (courts had no jurisdiction to hear Title VII Civil Rights Act 1964 employment claims between a church and its ministers); see Hosanna-Tabor at 13, n 2.

${ }^{17}$ Hosanna-Tabor at 6-9.

${ }^{18}$ Ibid. at 9-10.

${ }^{19}$ Ibid. at 10-12.

${ }^{20}$ Per Watson v Jones 13 Wall 679 (1872); Kedroff v Saint Nicholas Cathedral of Russian Orthodox Church in North America 344 US 94 (1952), at 116.

${ }^{21}$ Per Serbian Eastern Orthodox Diocese for United States and Canada v Milivojevich, 426 US 696 (1976).
} 
appointments. According the state the power to determine which individuals will minister to the faithful also violates the Establishment Clause, which prohibits government involvement in such ecclesiastical decisions. ${ }^{22}$

The SC rejected arguments that religious organisations could successfully defend against employment discrimination claims in those circumstances by invoking the constitutional right to freedom of association - a right 'implicit' in the First Amendment and that religious organisations had no protection beyond those of labour or social organisations. It stressed that it was the First Amendment itself, which gave 'special solicitude to the rights of religious organizations'. ${ }^{23}$ The SC also rejected the argument that the free exercise clause was not violated by a valid and neutral law of general applicability like the ADA, per Employment Division, Department of Human Resources of Oregon $v$ Smith. ${ }^{24}$ It the Smith case on the basis that it involved government regulation of only outward physical acts. ${ }^{25}$ In contrast, HosannaTabor concerned government interference with an internal church decision that affected the faith and mission of the church itself. In Smith the SC had distinguished the issues in that case from the government's 'lend[ing] its power to one or the other side in controversies over religious authority or dogma'. ${ }^{26}$

The SC then proceeded to hold that, on the facts of P's case, the ministerial exemption applied. It was clear, following every Court of Appeal decision on the issue, that the ministerial exception was 'not limited to the head of a religious congregation'. ${ }^{27}$ However, the SC was reluctant to adopt a rigid formula for deciding when an employee qualified as a minister. It considered it sufficient to establish that $\mathrm{P}$ was covered. Of critical importance was the formal title given to $\mathrm{P}$ by the Church ('Minister of Religion, Commissioned'); the substance reflected in that title in terms of tasks, responsibilities and training; her own use of that title; and the important religious functions she performed for the Church. P's duties reflected a role in conveying the Church's message and carrying out its mission. The SC identified one of the errors of the Appeals Court as being that it gave too much weight to the fact that lay teachers at the school performed the same religious duties as $\mathrm{P}$. Though relevant, this was not dispositive. Another error was that the Appeals Court placed too much emphasis on P's performance of secular duties. The amount of time an employee spent on particular activities was relevant in assessing that employee's status, but that factor could not be considered in isolation, without regard to the nature of the religious functions performed and the other considerations discussed above. ${ }^{28}$

The SC dealt with the suggestion, commonly made in discrimination cases, that the proffered ground of dismissal - that P violated the Synod's commitment to internal dispute resolution - was a pretext. There was some evidence for this. It was asserted that none of Hosanna-Tabor's communications with $\mathrm{P}$ during the relevant period mentioned the Synod's dispute-resolution process or P's failure to use it. P testified that she was not even aware of that process until Hosanna-Tabor raised it years later in this litigation. ${ }^{29}$ However, for the SC that suggestion missed the point of the ministerial exception. The purpose of the exception was not to safeguard a church's decision to fire a minister only when it was made for a religious

\footnotetext{
${ }^{22}$ Hosanna-Tabor, at 12-3.

${ }^{23}$ Ibid. at 14.

24494 US 872 (1990).

${ }^{25}$ In Smith this had involved ingesting peyote, a narcotic substance, which was a crime under Oregon law.

${ }^{26} 494$ US 872 at 877 (1990).

${ }^{27}$ Hosanna-Tabor at 15.

${ }^{28}$ Ibid. at $15-9$.
}

29 See Brief for the Federal Respondent, at 8, available at: http://www.justice.gov/osg/briefs/2011/3mer/2mer/2010-0553.mer.aa.pdf. [last accessed 1 August 2012]. 
reason. ${ }^{30}$ The exception instead ensured that the authority to select and control who would minister to the faithful - a 'strictly ecclesiastical' ${ }^{31}$ matter - was the church's alone. ${ }^{32}$ Thus religious autonomy even extends to dismissal for non-religious reasons.

Finally, the SC's Opinion ends with an express acknowledgment that societal interest in the enforcement of employment discrimination statutes is undoubtedly important. ${ }^{33}$ But, in the view of the SC, so too is the interest of religious groups in choosing who will preach their beliefs, teach their faith, and carry out their mission. In the SC's view, when a minister who had been fired sued her church alleging that her termination was discriminatory, the First Amendment had 'struck the balance for us'. ${ }^{34}$ The church must be free to choose those who will guide it on its way.

The 'ministerial exception' is a judge-made exception to the civil rights laws (and potentially others) based on the First Amendment. ${ }^{35}$ It has been accepted by the SC even though the Congress had made a conscious choice to include religious employers within the scope of the ADA. Although it provided certain defences for religion-based discrimination in employment, Congress had provided no comparable defence for a religious entity that retaliated against its employees for invoking their rights under the statute. ${ }^{36}$ The SC expressed "no view on whether the exemption bars other types of suits ${ }^{37}$ such as breach of contract or tortuous suits. ${ }^{38}$ However, it is clear that the ministerial exception is not limited to the ADA. Rather it bars suits brought on behalf of ministers against their churches, claiming termination in violation of employment discrimination laws. Although the SC states that the First Amendment has 'struck the balance for us', in fact there is no balancing in any real sense. If the exemption applies, it is absolute. By contrast with European jurisprudence it is odd that the balance is only struck in the First Amendment. There is no balancing between the rights in the First Amendment and those in other Amendments concerned with, for example, racial, gender and political equality. ${ }^{39}$ It is notable that the SC rejected the contentions of the Obama administration that the First Amendment provided no general ministerial exception and that religious organisations were limited to only the same right to freedom of association that labour unions and social clubs enjoyed. ${ }^{40}$

The ministerial exception covers both the selection of ministers and their dismissal or deselection. The term 'ministerial exception' gives a misleading impression. It potentially affects a very large number of people who work for religious organisations and are left with no protection against discrimination in the workplace. ${ }^{41}$ It has been reported that the US

\footnotetext{
${ }^{30}$ Hosanna-Tabor at 20 [emphasis added].

${ }^{31}$ Per Kedroff, supra n 21, at 119.

${ }^{32}$ See also the concurring opinion of Alito, joined by Kagan, in Hosanna-Tabor, at 8-10, on why probing for the real reason would require the courts to make a judgment about church doctrine and thereby pose grave problems for church autonomy.

${ }^{33}$ Hosanna-Tabor at 20.

${ }^{34}$ Ibid. at 21-2.

35 Turner has argued that the exception is 'actually a specific application of the constitutional avoidance doctrine, which provides that courts should interpret statutes so that their application will not risk violating constitutional principles'. See Turner, 'It's My Church and I Can Retaliate If I Want To: Hosanna-Tabor and the Future of the Ministerial Exception' (2011) 7 Duke Journal of Constitutional Law and Public Policy 21 at 26.

${ }^{36}$ On statutory exemptions in US law, see Furfaro and Salins, 'Religious Organizations Exemption' (2008) 239 New York Law Journal 1.

${ }^{37}$ Hosanna-Tabor at 20-21.

${ }^{38}$ See also Lupu and Tuttle, 'Sexual Misconduct and Ecclesiastical Immunity' [2004] Brigham Young University Law Review 1789.

${ }^{39}$ See in particular the Fourteenth Amendment on the 'equal protection of the laws'.

${ }^{40}$ See Brieffor the Federal Respondent, supra n 30, at 12, para c.

41 Griffin, 'The Sins of Hosanna-Tabor' (2013) 88 Indiana Law Journal [forthcoming], available at: http://ssrn.com/abstract=2026046 [last accessed 1 August 2012], refers to the rejection of lawsuits by 'elementary
} 
Census identified 429,000 Americans as members of the 'clergy' in $2010,{ }^{42}$ but it is clear that much higher numbers may fall within its scope. ${ }^{43}$ An individual may well believe, and indeed have been informed (as was the case with $\mathrm{P}$ ), that they are protected by employee protection legislation. They may not even realise they are a 'ministers' until their lawsuits are dismissed. The SC gave only limited guidance on who might be covered by the ministerial exception and that guidance must now be applied by lower courts. ${ }^{44}$ Justice Thomas' view was that the civil courts should defer to a religious organisation's 'good faith understanding of who qualifies as its minister': if a religious organisation 'sincerely considered' a person to be a minister that would be sufficient for him. ${ }^{45} \mathrm{He}$ was particularly conscious that the exemption should cover organisations with 'different leadership structures and doctrines that influence their conceptions of ministerial status' ${ }^{46} \mathrm{He}$ saw the question of who was a minister as itself a religious question. If his approach is followed it would meet the criticisms from those who are protective of religious autonomy and concerned about the intrusive exploration that the courts need to engage in so that they can determine whether a particular role is important to the spiritual and pastoral mission of the church. ${ }^{47}$ Justices Alito and Kagan, in their concurring opinion, suggested that the focus should not be on the term 'minister' or any conception of ordination. They noted that most faiths do not employ the term 'minister' at all and some had no concept of formal ordination. Rather the focus should be on the functions performed by persons who worked for religious bodies. The exception should be tailored to this purpose. It should, therefore, apply to any employee who 'leads a religious organization, conducts worship services or important religious ceremonies or rituals or serves as a messenger or teacher of its faith' ${ }^{48}$ For the SC the scope was clearly wider than that which the Court of Appeal in Hosanna-Tabor had afforded. ${ }^{49}$ Even before Hosanna-Tabor it was claimed that the ministerial exception had 'rapidly expanded, in part because of the difficulty of determining what constituted a ministerial office given the wide variety of leadership roles in different religions and in part because it was difficult to contain the logic of the exception to a single category of workers ${ }^{50}$ Moreover, it had provided blanket immunity so that even cases that appear to be wholly divorced from religious considerations still attracted the exception, leading to results that have left religious employees exposed to harsh and unfair treatment. ${ }^{51}$

and secondary school teachers, school principals, university professors, music teachers, choir directors, organists, administrators, administrative secretaries, communications managers and public relations personnel' (at 3).

${ }^{42}$ See Hallowel, 'Supreme Court Rules Against Abama Admin: Religious Employees Can't Sue for Job Discrimination' The Blaze, 11 January 2012, available at: www.theblaze.com/ [last accessed 1 August 2012]

43 See Peroni, 'U.S. Supreme Court and ECtHR: Conflicts between Religious Autonomy and Other Fundamental Rights' Strasbourg Observers, 2 February 2012, available at: http://strasbourgobservers.com/2012/02/02/u-s-supreme-court-and-ecthr-conflicts-between-religious-autonomyand-other-fundamental-rights/ [last accessed 1 August 2012].

${ }^{44}$ See Chopko and Parker, 'Still a Threshold Question: Refining the Ministerial Exception Post-Hosanna-Tabor' (2012) 10 First Amendment Law Review 233.

${ }^{45}$ Hosanna-Tabor, Concurring Opinion, at 1. A deferential approach was also advocated by the author of the Note, 'The Ministerial Exception to Title VII: The Case for a Deferential Primary Duties Test' (2008) 121 Harvard Law Review 1776 at 1790-7.

46 Ibid.

${ }^{47}$ Evans and Hood, supra n 8, at 104.

${ }^{48}$ Concurring Opinion of Alito, joined by Kagan, at 2.

${ }^{49}$ See Griffin, supra n 42, at 32-43. On preceding case law see 'The Ministerial Exception to Title VII: The Case for a Deferential Primary Duties Test', supra n 47 (noting that most Circuits had adopted a 'primary duties' test).

${ }^{50}$ Evans and Hood, supra n 8, 104.

${ }^{51}$ Ibid. citing Hopkins v Women's Div., Bd., Of Global Ministries 238 F. Supp. 2d. 174 (2002) (claims by the employee that she had been discriminated against based on race, religion and ethnicity), and Rosati v Toledo 233 F. Supp. 2d 917 (ND Ohio 2002) (court upheld the right of a Catholic Order to dismiss a novitiate who was diagnosed with breast cancer). 


\section{Fernández Martínez.}

Mr José Antonio Fernández Martínez (FM), a Spanish national, was ordained as a priest in 1961. In 1984 he applied to the Vatican for dispensation from celibacy. ${ }^{52}$ Before any dispensation had been granted he married in a civil ceremony in 1985, and he and his wife had five children. From 1991 onwards he was employed to teach Catholic religion and morals in a State high school. His contract was renewed every year by the Bishop of the Diocese of Cartagena. The Bishop's agreement was necessary under an agreement between Spain and the Holy See of 3 January 1979. In November 1996 the Murcia newspaper La Verdad published an article about the 'Movement for Optional Celibacy' for priests. It reported that FM, a member of the Movement, had previously been rector of a seminary and published a photograph of him attending a meeting of the Movement together with his wife and their five children. The article included comments by a number of participants urging the ecclesiastical authorities to introduce optional celibacy and democracy within the Church. In particular it raised the possibility for the laity to elect priests and bishops. It also indicated their disagreement with the Church's position on abortion, divorce, sexuality and contraception. On 15 September 1997 the Vatican authorities granted FM's application for dispensation from celibacy, specifying that anyone granted such a dispensation was barred from teaching the Catholic religion in public institutions, ${ }^{53}$ unless the local bishop decided otherwise 'according to his own criteria and provided that there is no scandal' (sans risquer le scandale). On 29 September 1997 the Diocese of Cartagena informed the Ministry of Education of its intention not to renew FM's contract for the 1997/98 school year. The Ministry notified FM of the decision. The Bishop's view was not based on his status as a married priest or as the father of five children. Rather it was that FM had indeed caused a 'scandal' by acting as a public spokesman for the Movement for the rights of priests to be married, by publicly presenting views in opposition to those of the Catholic authorities (on abortion, divorce etc) and by the publication of these views in the newspapers along with a photograph. It was on the basis of these factors that he could not be allowed to continue to be a teacher of Catholic religion and so his declaration of suitability had to be withdrawn.

FM appealed to the Murcia employment tribunal. That tribunal found that he had been discriminated against because of his civil status and his membership of the Movement for Optional Celibacy. It declared his dismissal null and void and ordered his reinstatement in his former post. The Ministry of Education, the regional education authority and the Catholic Diocese appealed. The High Court of Justice allowed the appeal. It examined the question of the bond of trust between the teacher and the Bishop, and emphasised the Bishop's prerogatives in ensuring that individuals in FM's position carried out their duties with discretion, making sure that their personal situation was not a source of scandal. If their situation became a public matter, it was the Bishop's duty not to renew their teaching contract. The Spanish appeal court noted that for the purposes of Article 10(2) of the ECHR, the restrictions imposed on FM's rights had to be considered proportionate to the aim pursued, namely the avoidance of scandal. The nature of the contract - the fact that it had to be renewed annually by the bishop - made it a temporary contract, which had simply expired. FM had therefore not been dismissed.

\footnotetext{
${ }^{52}$ In 2006, Vatican and other sources estimated that approximately 100,000 Catholic priests had abandoned their ministry to marry over the previous 40 years. Around 70,000 of them received papal dispensations from the vow of celibacy; see 'Vatican Summit Discusses Married Priests', available at http://www.adventgroup.org.uk/newsarchive-mainmenu-66/archive-mainmenu-95/298-vatican-summit-discusses-married-priests [last accessed 1 August 2012].

${ }^{53}$ Such a provision is common in the terms of dispensations.
} 
FM lodged an amparo appeal with the Constitutional Court. On 4 June 2007 the Constitutional Court dismissed the appeal. It highlighted the special role of teachers of religious education in Spain and found that the reasons for not renewing FM's contract had been purely religious. It further held that it would be unreasonable for the selection process for teachers of religious education not to take into account the candidates' religious beliefs. It considered that the duty of neutrality of the Spanish state with respect to religion in Article 16(3) of the Spanish Constitution meant that it could not evaluate the notion of 'scandal' in terms of canonical law and could do no more than satisfy itself that the refusal to renew FM's contract had been for exclusively religious reasons.

Relying on Articles 8 and 14 of the ECHR, FM alleged that the non-renewal of his contract because of his personal and family situation had infringed his right to respect for his private and family life before the ECtHR. He complained that he had been discriminated against and that the public disclosure of his status as a married priest with several children formed part of his freedom of expression. ${ }^{54}$ The ECtHR framed the question as whether the State was required to give precedence to FM's right under Article 8 (right to respect for private life) over the rights of the Church under Articles 9 (right to freedom of religion) and 11 (freedom of association) and whether it had afforded him sufficient protection. The ECtHR observed that under Spanish law the concept of autonomy of religious communities was accompanied by the principle of State neutrality in religious matters. This approach prevented the State from expressing a position on issues such as celibacy for priests. The ECtHR acknowledged that this obligation of neutrality was not unlimited. The Constitutional Court had confirmed on 4 June 2007 that restrictions could be imposed in this sphere through judicial review of decisions by the Bishop, who was required to respect fundamental rights and freedoms. However, the definition of the religious or moral criteria that served as a basis for not renewing a candidate's contract was the exclusive prerogative of the religious authority. The domestic courts could weigh up the competing fundamental rights at stake and examine whether the decision not to renew the contract had been based on anything other than strictly religious factors, those being the sole aspects protected by religious freedom. FM had had the opportunity to bring his case before the employment tribunal and the Murcia High Court of Justice, and had ultimately been able to lodge an amparo appeal with the Constitutional Court. Moreover, the decision dispensing him from celibacy had specified that anyone granted such a dispensation was barred from teaching the Catholic religion in public institutions except by permission of the bishop.

The ECtHR agreed with the Constitutional Court that the grounds upon which FM had not had his contract renewed were of a strictly religious nature. ${ }^{55}$ Significantly, the requirements of the principles of religious freedom and neutrality prevented the ECtHR from further consideration of the necessity and proportionality of the decision not to renew. Rather the ECtHR held that its role should be limited to verifying that the fundamental principles of domestic law or the complainant's dignity were not compromised. ${ }^{56}$ The non-renewal decision had only been taken after the article had been published, publicity given to the seminar and the arguments against the teachings of the church made public. It was these events that led the Bishop to consider that the

\footnotetext{
${ }^{54}$ In view of its finding on Article 8 the ECtHR considered that no separate issue arose under article 14 taken alone or in conjunction with articles 8 or 10. FM also complained that there had been a violation of Article 6 ECHR as two of the judges who had delivered the Constitutional Court judgment had not been impartial and should have stood down because their religious beliefs favoured the Catholic Church. The ECtHR held that FM had produced no evidence to support his allegation that he had not been aware until after the Constitutional Court's judgment of the alleged lack of impartiality. Moreover, FM had not used all the means available to him in domestic law to challenge the impartiality of the judges concerned and thus his complaint was inadmissible for failure to exhaust domestic remedies.

${ }^{55}$ Fernández Martínez at para 84.

${ }^{56}$ Ibid.
} 
special bond of confidence (lien de confiance spécial) required was broken and to not renew the contract. ${ }^{57}$ The bond necessarily implied certain specificities (in the sense of professional requirements) which differentiated teachers of Catholic religion and morals from other teachers. ${ }^{58}$ The ECtHR held that the conclusions of the Spanish domestic courts were not unreasonable. ${ }^{59}$ When FM had begun to teach he had not yet received a waiver from the Vatican that made him a 'married priest' in the eyes of the Catholic Church. In protecting the collective dimension religious of religious freedom, account could be taken of the religious convictions of FM, including the obligations of loyalty FM had submitted to in accepting the dispensation from the Vatican. The ECtHR compared FM's obligations with those in the case of Obst ${ }^{60}$ in which a Director of Public Relations for Europe for the Mormon church who, having grown up in the Church, was or should have been aware, when signing his contract, of the importance of marital fidelity to his employer. Therefore he should have been aware of the incompatibility of the extra-marital relations he had chosen to establish with the increased obligations of loyalty he owed to the Church as a Director.

The Court also contrasted FM's obligations with those in the case of Schüth ${ }^{61}$ an organist and choirmaster in a Catholic parish. In his case the ECtHR considered that although there were obligations of loyalty to the Catholic Church, S's signature of his contract could not be interpreted as an unequivocal personal commitment to live in abstinence in separation or divorce. Such an interpretation would affect the core of the right to respect for privacy of the person concerned, especially since, as the labour courts had found, S was not subject to increased duties of loyalty. $\mathrm{S}$ had stated that he could not prevent the separation from his wife for strictly personal reasons and that it was not possible to live in abstinence until the end of its days, as would require the canonical code of the Catholic. S's situation did not concern the dismissal of a person because of his public statements against the moral position of his church employer. S had not publicised his position and in 14 years of service to the parish, he had not fought the positions of the Catholic Church. Rather he had simply failed to observe them in practice in matters that were at the core of S's private life. By contrast, FM had not been unwillingly exposed by the Press. Rather he had, along with others in the Movement, openly expressed their disagreement with the policies of the Church in several areas. ${ }^{62}$ The particular nature of the professional requirements imposed on FM was due to the fact that they had been established by an employer whose ethics was based on religion or belief. The competent national courts had sufficiently demonstrated that the obligations of loyalty were acceptable, in that they were intended to preserve the sensitivity of the public and the parents of the pupils of the school. The reasoning of those courts was sufficiently detailed. ${ }^{63}$ In addition, the ECtHR considered that the requirement of reserve and discretion was all the more important given that the direct recipients of the teachings of FM were minor children, who were vulnerable and impressionable by nature. ${ }^{64}$ The ECtHR also noted that after the non-renewal FM had found work in a museum and continued to work there until retirement. ${ }^{65}$ In conclusion, having regard to the state's margin of appreciation and the fact that the competent courts had struck a 'fair

\footnotetext{
57 Ibid.

${ }^{58}$ Ibid. at para 85 .

${ }^{59}$ Ibid. at para 86.

${ }^{60}$ Application no 425/03, Merits, 23 September 2010, at para 50. [The judgment is available only in French].

${ }^{61}$ Application no 1620/03, Merits, 23 September 2010, at para 71. [The judgment is available only in French.]

62 Id.

${ }^{63}$ Ibid. at para 87. This was considered not to have been the case in Schüth, supra n 64 at para 66.

${ }^{64}$ Ibid. at para 87, citing Dahlab v Switzerland 2001-V (on impact of a powerful external symbol, an Islamic headscarf, on young children).

${ }^{65}$ Fernández Martínez at para 88. It contrasted this with what had happened to Schüth, who had limited possibilities to find new employment, see infra $\mathrm{n} 64$.
} 
balance' between several private interests, the Court unanimously found that there had been no violation of Article $8 .^{66}$

The ECtHR accepted the argument of the Spanish Constitutional Court that the nature of the 'motivé' (reasons) for the non-renewal were strictly religious. ${ }^{67}$ It stressed that Spanish law guaranteed religious communities a degree of autonomy and that the Spanish Constitution recognised the principle of the religious neutrality of the state. The Spanish Constitutional Court's interpretation of this principle had included an appreciation of the necessity to balance individual rights against the rights of the Church. However, the ECtHR effectively deferred to the Church's autonomous assessment as (and this was noted by Judge ad hoc Saiz Arnaiz) the ECtHR did not engage in a balancing exercise. Instead, it deferred to the balancing exercise undertaken by the national court. An observer of the ECtHR's jurisprudence might well have expected that court to insist on a balancing exercise and, therefore, for much to turn on the proportionality of the decision on the facts of the case. ${ }^{68}$ This is what the ECtHR had done in Obst v Germany ${ }^{69}$ and Schüth v Germany, ${ }^{70}$ in which it held that the domestic courts were required to balance the rights of both parties; and that such a balancing exercise included the proximity of the activity of the applicant to the mission of the Church, the specific nature of post concerned and the possibility for the applicant to find new employment.

Mr Schüth, had been the organist and choirmaster in the Catholic parish of St Lambert in Essen since the mid-1980s, when he separated from his wife in 1994. From 1995 onwards he lived with his new partner. In July 1997, after his children had spoken in kindergarten about the fact that their father was going to have another child, the dean of the parish held a meeting with S. A few days later, the parish informed him of his dismissal as of April 1998, on the grounds that he had violated the basic regulations of the Catholic Church on employment with the Church. In particular, by engaging in an extra-marital relationship with another woman who expected a child from him, he had not only committed adultery but was also guilty of bigamy. Obst grew up in the Mormon faith and married in 1980 in accordance with Mormon rites. After holding various positions within the Mormon Church, he was appointed to the post of Director of Public Relations for Europe in 1986. Obst's marriage had been deteriorating for years and that he had an affair with another woman. Obst was dismissed without notice. Obst was subsequently excommunicated by way of an internal disciplinary procedure.

Both Schüth's and Obst's proceedings in the national courts failed. The Federal Labour Court referred to a leading judgment by the Federal Constitutional Court of 4 June 1985 concerning the lawfulness of the dismissal of Church employees after a violation of their loyalty obligations. Following this judgment, Church employers had the right to govern their affairs in an autonomous manner, while at the same time labour courts were bound by the principles of the Church employers' religious and moral precepts to the extent that they did not conflict with the fundamental principles of the legal order of the State. The requirements of the Catholic Church concerning marital fidelity were not considered to conflict with the fundamental principles of the legal order. With respect to Schüth, given his determined stance to uphold his new relationship, the dean had rightly been able to assume that an advance warning would have been superfluous. The court held that the parish could not continue employing him as organist without losing all credibility, as his activity was closely connected to the Church's mission. Schüth's complaint to the Federal Constitutional Court was dismissed

\footnotetext{
${ }^{66}$ Fernández Martínez at para 84. The Spanish Ad hoc Judge Saiz Arnaiz expressed a separate opinion in which he disagreed with the majority decision on Article 8.

${ }^{67}$ Fernández Martínez at para 84.

${ }^{68}$ See Leigh, 'Balancing Religious Autonomy and Other Human Rights under the European Convention' (2012)

1 Oxford Journal of Law and Religion 109.

69 Supra $n 63$.

70 Supra n 64.
} 
with reference to its leading judgment of 4 June 1985. With respect to Obst the national court held that he had not honoured the obligations arising from provisions in his work contract. According to the Federal Labour Court, the requirements of the Mormon Church regarding marital fidelity did not conflict with the fundamental principles of the legal order, because marriage was also of pre-eminent importance under the German Basic Law. The dismissal had been necessary for the Church to keep its credibility, which was under threat in view of Obst's responsibilities as Director of Public Relations for Europe. Moreover, the Church had not been obliged to give an advance warning, as, given his long career with the Church, Obst must have been aware of the severity of his misconduct. Again the Federal Constitutional Court dismissed a constitutional complaint with reference to its leading judgment of 4 June 1985.

The ECtHR unanimously concluded that there had been no violation of Article 8 in Obst's case but that there had been a violation of Article 8 in Schüth's case. What is of significance for our purposes is that in both cases the ECtHR examined whether the balance struck by the German labour courts, between the applicants' right to respect for their private life under Article 8 on the one hand and the ECHR rights of the Catholic and the Mormon churches on the other, had afforded the applicants sufficient protection. It reiterated that the autonomy of religious communities was protected against undue interference by the State under Article 9 (freedom of religion) read in the light of Article 11 (freedom of assembly and association). By putting in place a system of labour courts and a constitutional court having jurisdiction to review the former courts' decisions, Germany had, in principle, complied with its positive obligations towards litigants in the area of employment law. The applicants had been able to bring their cases before a labour court with jurisdiction to determine whether the dismissal had been lawful under State labour law while having regard to ecclesiastical labour law. In both cases, the Federal Labour Court had found that the requirements of the Mormon Church and the Catholic Church, respectively, regarding marital fidelity did not conflict with the fundamental principles of the legal order.

As regards Obst, the ECtHR observed that the German labour courts had taken account of all the relevant factors and undertaken a careful and thorough balancing exercise regarding the interests involved. They had pointed out that the Mormon Church had only been able to base Obst's dismissal on his adultery because he had informed the Church of it by his own initiative. According to the German courts' findings, his dismissal amounted to a necessary measure aimed at preserving the Church's credibility, having regard in particular to the nature of his post. The courts had explained why the Church had not been obliged to inflict a less severe penalty, such as a warning, and they had underlined that the injury suffered by Obst as a result of his dismissal was limited, having regard among other things to his relatively young age. Importantly, the fact that, after a thorough balancing exercise, the German courts had given more weight to the interests of the Mormon Church than to those of Obst, did not, of itself, raise an issue under the ECHR. The conclusion that Obst had not been subject to unacceptable obligations was reasonable, given that, having grown up in the Mormon Church, he had, or should have, been aware when signing the employment contract of the importance of marital fidelity for his employer and of the incompatibility of his extra-marital relationship with the increased duties of loyalty he had contracted towards the Church as director for Europe of the public relations department.

By contrast, as regards Schüth, the ECtHR observed that the labour court of appeal had confined itself to stating that while his functions as organist and choirmaster did not fall within the group of employees who in case of serious misconduct had to be dismissed, namely those working in counselling, in catechesis or in a leading position, his functions were nonetheless so closely connected to the Catholic Church's proclamatory mission that the parish could not continue employing him without losing all credibility. That court had not examined this argument any further but appeared to have simply reproduced the opinion of the Church 
employer on this point. The labour courts had moreover made no mention of Schüth's de facto family life or of the legal protection afforded to it. The interests of the Church employer had thus not been balanced against Schüth's right to respect for his private and family life, but only against his interest in keeping his post. A more detailed examination would have been required when weighing the competing rights and interests at stake. While the ECtHR accepted that in signing the employment contract, Schüth had entered into a duty of loyalty towards the Catholic Church that limited his right to respect for his private life to a certain degree, his signature on the contract could not be interpreted as an unequivocal undertaking to live a life of abstinence in the event of separation or divorce. The German labour courts had given only marginal consideration to the fact that Schüth's case had not received media coverage and that, after 14 years of service for the parish, he did not appear to have challenged the position of the Catholic Church. The fact that an employee who had been dismissed by a church employer had only limited opportunities of finding another job was also of particular importance. This was all the more so where the dismissed employee had special qualifications that made it difficult, or even impossible, to find a new job outside the Church, as was the case with Schüth, who now worked part-time in a Protestant parish. In that connection the ECtHR noted that the rules of the Protestant Church relating to church musicians stipulated that non-members of the Protestant Church might only be employed in exceptional cases and solely in the context of an additional job. In conclusion, the ECtHR found that the German labour courts had failed to weigh Schüth's rights against those of the Church employer in a manner compatible with the ECHR.

The careful balancing approach in these cases was followed in Siebenhaar $v$ Germany, ${ }^{71}$ which concerned a conflict between the rights of a church and the rights of an individual to religious freedom. The ECtHR found no violation in S's dismissal from her job in a kindergarten run by a Protestant parish on the grounds of her active involvement in another religious community, the Universal Church of Humanity. The Protestant Church in Germany required loyalty from its employees. One consequence of this was that employees should not be members of or collaborate with organisations whose principles contradicted those of the Protestant Church. In Siebenhaar the German labour courts had taken account of all the relevant factors and undertaken a careful and thorough balancing exercise regarding the interests involved. According to the courts' findings, S's dismissal had been necessary to preserve the Church's credibility, which outweighed her interest in keeping her job. The courts had also taken into consideration the relatively short duration of her employment. As with $\mathrm{Obst}$, the fact that, after that thorough balancing exercise, they had given more weight to the interests of the Protestant Church than to those of $\mathrm{S}$ did not itself raise an issue under the ECHR. The ECtHR also found the German labour courts' findings reasonable. S had, or should have, been aware from the moment of signing her employment contract that her activities for the Universal Church were incompatible with her work for the Protestant Church. ${ }^{72}$

The balancing approach in Obst, Schüth and Siebenhaar represented a notable change in jurisprudence from the previous approach under which virtually absolute weight was given

\footnotetext{
${ }^{71}$ Application no 18136/02, Merits, 3 February 2011. [The judgment is available only in French.] See also Baudler $v$ Germany Application no 38254/04, Admissibility, 6 December 2011; Reuter v Germany Application no 39775/04, Admissibility, 6 December 2011; and Müller v Germany Application no 12986/04, Admissibility, 6 December 2011 (alleged violations of right of access to court held inadmissible.) In Müller the applicants had been able to raise their complaint before the civil courts, but they complained of the limited scope of the courts' review. This limitation arose out of the right to autonomy of Churches and religious societies under Article 137(3) of the Weimar Constitution. The ECtHR observed that the German courts had attached weight to the fact that the applicants had not appealed against their dismissal before the Salvation Army board of inquiry. The courts had concluded that there were no grounds for finding that the Salvation Army's decision had been arbitrary or contrary to public morals or public policy. Accordingly, in the ECtHR's view, the applicants could not argue that they had been deprived of the right to obtain a decision on the merits of their claim.

72 The GC rejected a request for referral.
} 
to the interests of the various churches on the basis that the individual always had the right of exit if they disagreed with, or wished to engage in practices contrary to, those interests. ${ }^{73}$ As Evans and Hood have acknowledged, the balancing approach is far more complicated for religious groups to predict or comply with than the procedural limitations as ' $t]$ hey may require them to give - or at least feign giving — consideration to secular values that they may not share (such as respect for the private or family life of those that it considers to be living in relationships that do not deserve respect). ${ }^{, 74}$ It creates unpredictability as to whether domestic courts, after weighing a range of complex factors, will uphold their religious autonomy in particular cases or not. ${ }^{75}$ As they note, " $[\mathrm{t}]$ he best outcome of this weighing and balancing approach might be one that will encourage both sides to try to act reasonably in coming to a fair outcome. The worst will be increased litigation and micromanagement of employment decisions by courts'. ${ }^{76}$

The ECtHR went to great lengths to explain how its approach in the Fernández Martínez sat with its approach in the German cases. It stressed that $F M$ had not hidden from the press and had thus contributed to the publicity given to his private and family life, while the applicant in Schüth had not taken such action. FM had been able to rely on unemployment benefits and had found a job at a museum after his dismissal, while one of the features of the Schüth case had been that the applicant had faced major difficulties in finding new employment. The primary argument used by the ECtHR to distinguish Fernández Martinez from the need for ad hoc balancing in Schüth, Obst and Siebenhaar concerned the nature of the FM's functions. It observed that all its previous judgments in similar cases [which cases did it refer to] had concerned measures taken by church authorities vis-à-vis lay persons, whilst FM was a 'secularised priest'. The Court also considered that, unlike the applicant in Schüth, he had been under an increased obligation of loyalty, which he had violated - in the eyes of the Church - when he became publicly known as a 'married priest', thereby causing a 'scandal'. However, the applicant in Obst had also been under an increased obligation of loyalty according to the Court. Therefore, it was arguably the nature of the FM's position as a priest that wished to continue to teach Catholic morals that set Fernández Martínez apart from the previous cases, leading the ECtHR to accept the Spanish courts' balancing, instead of insisting on a more thorough ad hoc balancing.

\section{Preston}

The protection of individual religious freedom and the autonomy of religious organisations within the jurisdictions of the UK are legally and politically complex. ${ }^{77}$ There are degrees of free exercise and of formal and informal establishment. ${ }^{78}$ These are now overlaid by the rights protected by the ECHR via the Human Rights Act 1998.

Following a period as a Probationer Minister, $\mathrm{M}$ was ordained as a Methodist Minister in $2003 .{ }^{79}$ In 2006 she was appointed to the post of Superintendant Minister to the Redruth Circuit in Cornwall. In June 2009 she submitted a letter of resignation. In September 2009 she commenced proceedings in the Employment Tribunal (ET) alleging unfair constructive dismissal. Her claim raised a preliminary issue of whether was she an 'employee' of the

\footnotetext{
${ }^{73}$ See Leigh, supra n 71, 120-5.

${ }^{74}$ Evans and Hood, supra n 8, 103.

${ }^{75}$ Id.

${ }^{76} \mathrm{Id}$.

77 See Rivers, supra n 1.

${ }^{78}$ See McLean and Peterson, 'Entrenching the Establishment and Free Exercise of Religion in the Written U.K. Constitution' (2011) 9 International Journal of Constitutional Law 230.

${ }^{79}$ In technical Methodist terms the language used is that she was received in 'full connexion' with the Methodist Church.
} 
Church within the meaning of s. 230 of the Employment Rights Act $1996^{80}$ The ET, following the 1984 decision of the Court of Appeal in President of the Methodist Conference $v$ Parfitt, ${ }^{81}$ held that she was not an employee of the Church and so dismissed the claim. The essence of the decision in Parfitt was that the relationship between a Minister and a Church was a spiritual one, not a contractual one. There was a rebuttable presumption of an absence of intention to create legal relations. Dillon LJ saw no good reason why 'modern economic conditions or the development of social security and employment protection should lead to a different conclusion now ${ }^{82} \mathrm{M}$ appealed. The Employment Appeal Tribunal (EAT) ${ }^{83}$ allowed the appeal, concluding that the reasoning in Parfitt could not be sustained in the light of 2006 decision of the House of Lords in Percy v Board of National Mission of the Church of Scotland. ${ }^{84}$ In Percy, a female Minister of the Church of Scotland, was held to have had 'a contract personally to execute...work' for the purposes of the Sex Discrimination Act 1975. ${ }^{85}$ In Percy the HL saw 'no cogent reason today to draw a distinction between a post whose duties are primarily religious and a post within the Church where this is not so' ${ }^{86}$ It considered that it was 'time to recognise' that employment arrangements between a church and its ministers should not lightly be taken as intended to have no legal effect 'and, in consequence, its ministers denied [statutory] protection'. ${ }^{87}$ In Preston ${ }^{88}$ the Court of Appeal upheld the reasoning and decision of the EAT. M's relationship with the Church was contractual and the contract was one of 'employment'. The Court considered that in Percy the House of Lords had rejected the idea that there was a rebuttable presumption that there was no intention to create legal relations. ${ }^{89}$ Without more evidence, it was illegitimate to rely on the spiritual nature of the role to create such a presumption or to rely on it as the basis of a specific finding of no such intention. ${ }^{90}$

The Methodist Church sought to rely on Article 9 of the ECHR. However, the Court of Appeal regarded the potential role of Article 9 in such cases as modest. It cited the view of Arden LJ in New Testament Church of God $v$ Stewart ${ }^{91}$ that the fact that in an employment dispute one party to the litigation was a religious body or that the other party was a minister of religion did not of itself engage Article 9. For Article 9 to be engaged there must be religious beliefs that are contrary to, or inconsistent with, the implication of the contract or a contract of employment. It followed that the implication of a contract of employment was not automatically an interference with religious beliefs. ${ }^{92}$ The Court of Appeal was doubtful whether giving one party contractual or statutory remedies could be regarded as a limitation or,

\footnotetext{
${ }^{80}$ Section 230 provides: '(1) In this Act 'employee' means an individual who has entered into or works under (or, where the employment has ceased, worked under) a contract of employment. (2) In this Act 'contract of employment' means a contract of service or apprenticeship, whether express or implied, and (if it is express) whether oral or in writing'.

${ }^{81}$ [1984] ICR 176.

82 Ibid. at 185.

${ }^{83}$ Moore v President of the Methodist Conference UKEAT/0219/10/DM, 15 March 2011.

${ }^{84}$ [2005] UKHL 73. The HL held that it had jurisdiction over the case and that the Sex Discrimination Act 1975 applied to the church.

${ }^{85}$ Lord Hoffmann dissented but on the basis that $\mathrm{P}$ was an office holder rather than an employee even in the wider sense predicated by the Sex Discrimination Act, but he accepted that an office holder could also be an employee. ${ }^{86}$ Supra n 88, per Lord Nicholls, para. 25.

${ }^{87}$ Ibid. at para 26.

88 [2011] EWCA Civ 1581; [2012] 2 All ER 934 (hereinafter Preston).

${ }^{89}$ See the opinions of Lord Hope at para 112, Baroness Hale at para 151, and Lord Scott at para 137 in Percy, supra $\mathrm{n}$ 88. The intention could still be determined but it could not be presumed, see New Testament Church of God v Stewart [2008] ICR 282. In the latter case Percy was seen as an instance of the courts fulfilling their timehonoured role of updating the common law and making it more suitable for modern circumstances, per Arden LJ at para 64.

${ }^{90}$ Preston at paras 22-5.

${ }^{91}$ Supra $n 93$.

${ }^{92}$ Ibid. at para 62.
} 
an interference with, the right to freedom of thought, conscience and religion under Article 9 even if was contrary to the to the belief of one of the parties, there was, or should be, no contract. $^{93}$

The Methodist Church made reference to Church doctrine on Ministers as 'stewards' and that their office depending on the call of God. However, for the Court of Appeal, this 'priesthood of all believers' (the idea that every member of the Church has a responsibility to teach and expound the Christian faith) did not embrace a doctrinal belief that a Minister who was treated with unfairness or discrimination must be denied common legal redress. ${ }^{94}$ The Methodist Church submitted that the existence of a contract of employment might interfere with the right of Methodists to manifest their religious belief because of the implications of accountability in an employment tribunal and the financial costs involved. For the Court of Appeal this only served to emphasise the 'unattractiveness and moral poverty of the attempted invocation of Article 9 in this case' ${ }^{95}$ The Court of Appeal agreed with the EAT's conclusion that this was not a case where the evidence established that the existence of a contract of employment between the Church and a Minister was contrary to its tenets and it could not conceive that any claim within the jurisdiction of an employment tribunal would require it to determine disputed issues of doctrine. ${ }^{96}$ Thus the UK courts do not see a need for a HosannaTabor-type immunity as the mechanism for staying away from getting involved in determining doctrinal issues. ${ }^{97}$ Having established that a Minister could be an employee, it is for an employment tribunal to decide on the facts whether or not the statutory criteria of unfairness or discrimination has been met in any individual case. ${ }^{98}$ As noted, any degree of balancing of rights necessarily gives less protection to the interest of religious organisations in autonomy than does a Ministerial exception.

Treating ministers as employees brings them within the scope of employment protection. If a minister is found to be an employee, any decision to dismiss will be unfair unless a potentially fair reason is provided, such as conduct, capability or some other substantial reason justifying the dismissal. The breadth of the catch-all some other substantial reason gives scope for religious reasons to be the justifying reason for dismissal. Once the fair reason is established, then it needs to be shown that it was reasonable to rely on that reason. Again the religious context can then be taken into account in assessing reasonableness. For discrimination law, if the discrimination is indirect, then it can be justified if for a legitimate aim and proportionate. Both these terms would be interpreted taking the religious context into account. For direct discrimination, it will only be lawful if the occupational requirement is shown, again needing to be proportionate and again allowing religion to be taken into account.

However, that law may itself give a specific and narrowly defined space to the protection of the autonomy interests of religious organisations via exemptions. Beyond those exemptions, it is arguable that what is fair or non-discriminatory for a religious organisation to do to its employees might well not be fair or non-discriminatory (in terms of a reasonable and objective justification) for a secular organisation to do to its employees. A practical problem is that views of religious organisations are not monolithic. Within any particular Church or faith there

\footnotetext{
93 Preston at para 32, following Lawrence Collins LJ in Stewart supra n 93 at para 66.

${ }^{94}$ Ibid. at para 33. Duddington has questioned whether the courts are properly marking the distinction between church and state by avoiding adjudication on theological matters. He suggests that the CA arguably overstepped this boundary in Moore/ Preston by ruling that a Methodist minister was an employee of the church despite its doctrine of 'the priesthood of all believers'; see Duddington, 'Case Comment' (2011) 166 Law and Justice 3-4. See generally Rivers, supra n 1, ch. 4.

${ }^{95}$ Ibid. at para 34.

${ }^{96}$ Ibid.

${ }^{97}$ See Edge, supra n 2.

${ }^{98}$ Preston at para 37.
} 
may be a broad range of views. Their constituent members and constituent elements may have a spectrum of views in relation to the conduct of a particular person. What is done by one institution within a religious organisation might not be done in another. What is tolerated in one may not be tolerated in another. Courts and tribunals will have to be sensitive to these differences.

Treating ministers as employees will normally make the application of the principle of the employer's vicarious liability for the employee clearer. However, vicarious liability involves different and more complex policy objectives. It can extend beyond the employee context to one where the relationship is sufficiently akin or close in character to employment ${ }^{99}$ or where a body exercised effective control over the work done by particular persons. ${ }^{100}$ The decisions are fact specific and the UK courts are now more open to the idea of dual vicarious liability. ${ }^{101}$

\section{Legal Spaces or Black Holes}

Obviously the approaches of the respective courts in the decisions considered above have to be understood within their own legal and political contexts. ${ }^{102}$ Nonetheless, there are many respects in which the contrasts are striking. As with any other legal immunity, ${ }^{103}$ the Ministerial exception in Hosanna-Tabor is highly protective of the interest it protects, which in that case was the autonomy of religious organisations. US discrimination laws already contain specific defences for religious organisations, but the ministerial exception is a wider immunity stemming from an interpretation of the US Constitution. There is no procedural protection, as US courts will not even inquire into whether a particular Church has followed its own

\footnotetext{
${ }^{99}$ See JGE v. The Trustees of the Portsmouth Roman Catholic Diocesan Trust [2012] EWCA Civ 938 (12 July 2012) (majority decision that the relationship between a Roman Catholic Diocesan Bishop and a parish priest was, on the facts, sufficiently akin to employment that was just and fair to hold the Bishop vicariously liable for the acts of sexual abuse of a child allegedly committed by the priest). The CA gave detailed but not uncritical attention to the decision of the Supreme Court of Canada in John Doe v Bennett [2004] 1 SCR 436, [2004] SCC 17 on the application of the doctrine of vicarious liability to the tort of sexually assaulting children ${ }^{100}$ See Various Claimants $v$ Catholic Child Welfare Society and Others and Institute of the Brothers of the Christian Schools [2010] EWCA Civ 1106, 26 October 2010 (unreported) (on the facts the Institute was not vicariously liable for sexual abuse of children by members (Brothers) of the Institute who were headmasters of, or who taught at, a school). The UK Supreme Court heard an appeal in the case in July 2012.

${ }^{101}$ Viasystems (Tyneside) v Thermal Transfer (Northern) Ltd [2006] QB 510, paras 46-49, per May LJ.

${ }^{102}$ Cf Movsesian, 'Crosses and Culture: State-Sponsored Religious Displays in the US and Europe' (2012) 1 Oxford Journal of Law and Religion 00 (the different conceptions of neutrality reflect institutional and cultural realities. In particular, the differences reflect what sociologists of religion describe as the 'American' and 'European' religious models).

103 The ECtHR has accepted that the operation of diplomatic and state immunity can be consistent with the ECHR. For a notable inroad into state immunity in an employment context see Cudak v Lithuania, Application no 15869/02, Merits, 51 EHRR 15 (by declining jurisdiction to hear the C's claim of sexual harassment and accepting the Polish Government argument of State immunity, the Lithuanian courts' decisions had impaired the very essence of C's right of access to a court in violation of Article 6(1) ECHR). The ECtHR observed that there was a trend in international law, confirmed with the adoption at the UN-level of two international legal documents - the 1991 Draft Articles and the 2004 Convention on Jurisdictional Immunities of States and their Property - towards limiting the application of State immunity, notably by exempting contracts of staff employed in a State's diplomatic missions abroad from the immunity rule.
} 
procedures. ${ }^{104}$ It is also notable that the SC included no reference to any comparative law or to international human rights treaties or jurisprudence. ${ }^{105}$

Even within the context of US constitutional law, however, the ministerial exception seems open to criticism. ${ }^{106}$ It has been suggested that it is constitutes a profound misinterpretation of the First Amendment and is based on a narrow and limited historical understanding. ${ }^{107}$ The exception effectively allows religious organisations to discriminate but justify it on a doctrinal pretext. ${ }^{108}$ Its scope is very wide in terms of the personnel it covers. No matter how clear the discrimination on the facts those individuals are left defenceless. The overarching criticism is that which attends all immunities, namely that the beneficiaries, in this case the religious organisations, are effectively placed above or outside of the law and so entitled to disobey it. ${ }^{109}$ Hosanna-Tabor appears to create a legal vacuum where the law does not go. It creates a vacuum in the sense that it is a space which is empty of legal principles. The decision of the religious authority is not controlled or regulated by law. Absolute and arbitrary power is subject to no legal control. Women are likely to be disproportionately affected in terms of gender discrimination (one case concerned resort to in vitro fertilisation), pregnancy discrimination, sexual harassment, hostile work environment and unequal pay. ${ }^{110}$ No matter how suspect the ground of discrimination - even race - the exception applies. Although Hosanna-Tabor was an explicitly discrimination case (disability discrimination), the SC affirmed the doctrine and application of a ministerial exception beyond this area. Even what would be a directly discriminatory measure escapes being subjected to any legal principles or standards of review. Thus Churches are not subjected to discrimination laws, many of which they have actively supported as consistent with their own religious values and beliefs, as long as narrow statutory exemptions are granted to them. Religious individuals must obey neutral laws of general applicability (per Smith), but not so for religious institutions which, ironically, become a law unto themselves. ${ }^{111}$ If Obst (a director of public relations), ${ }^{112}$ Schüth (an organist

\footnotetext{
${ }^{104}$ Per Serbian Eastern Orthodox Diocese for United States and Canada v Milivojevich 426 US 696 (1976). Evans and Hood, supra $\mathrm{n} 8$ at 105, observe that the procedural approach developed in Lombardi Vallauri Application no 39128/05, Merits, 20 October 2009, represents an intrusion into religious autonomy but they consider that it may provide a reasonable balance between the rights of employees and religious groups.

${ }^{105}$ In the US there has been controversy on the propriety or otherwise of such references. For a helpful overview see Garcia, 'International Law and Agreements: Their Effect Upon U.S. Law'Congressional Research Service, January 26, 2010, available at http://www.fas.org/sgp/crs/misc/RL32528.pdf [last accessed 1 August 2012]. In $R$ (Animal Defenders International) $v$ Secretary of State for Culture, Media and Sport [2008] UKHL 15, [2008] $1 \mathrm{AC} 1312$ at para 47, Baroness Hale described US First Amendment jurisprudence on campaign spending as 'the elephant in the committee room, always there but never mentioned'.

${ }^{106}$ See Griffin, supra n 42; and Turner, supra n 36 (who assumed that the SC would not reverse the Court of Appeals' judgment).

107 ' $[\mathrm{U}]$ sing English history to overcome civil rights legislation approved by Congress defies the rule of law', Griffin, ibid. at 13.

${ }^{108}$ Griffin, ibid. at 17-31. Cf McDonnell Douglas Corporation v Green 411 US 792 (1973) in which a burdenshifting approach was adopted to allow courts to determine the real reason for a termination without assessing the wisdom of the proffered reason itself.

${ }^{109}$ See Fish, 'Is Religion above the Law' The Opinion Pages, New York Times, 17 October 2011, available at http://opinionator.blogs.nytimes.com/2011/10/17/is-religion-above-the-law/ [last accessed 1 August 2012]; and Griffin, supra $n$ 42, 5 .

${ }^{110}$ See Waters, 'Testing Hosanna-Tabor: The Implications for Pregnancy Discrimination Claims and Employees' Reproductive Rights' 9 Stanford Journal of Civil Rights and Civil Liberties (forthcoming) available at: http://ssrn.com/abstract=2088108 [last accessed 1 August 2012]; Griffin, supra n 42 at14-15; Rosati v Toledo, supra n 53; and Petruska v Gannon University 462 F.3d 294 (3rd Circuit, 2006).

${ }^{111}$ Cf Smith, 494 US at 879.

${ }^{112}$ Cf Alicea-Hernandez v Catholic Bishop of Chicago 320 F.3d 698 (7th Cir. 2003) (Hispanic Communications Manager could not bring Title VII national origin claim).
} 
and choirmaster) ${ }^{113}$ and Siebenhaar (a kindergarten teacher in a Church school) had been in America it appears their cases would have fallen within the ministerial exception. All of this leaves religious organisations subject to criticism particularly when they themselves claim the benefit of constitutional or human rights. ${ }^{114}$ It gives ammunition to those who are hostile to the notion of giving religions increased autonomy. ${ }^{115}$

Central to the ruling in Hosanna-Tabor was acceptance of the Church's view that it was contrary to religious belief to sue the Church. The UK courts have accepted that if there was a religious belief that there was no enforceable contractual relationship, then that is a factor in determining whether the parties must be taken to have intended to enter into a legally binding contract. ${ }^{116}$ But that would be a very rare case. ${ }^{117}$ It would necessarily require the court to determine as a fact whether or not a contractual relationship would be inconsistent with religious doctrine or text or with the practice and beliefs at the particular religious institution. ${ }^{118}$ The SC in Hosanna-Tabor clearly saw litigation between a religious body and a minister of religion as raising central issues of religious freedom. By contrast, in Moore/ Preston the CA was doubtful that if, contrary to the belief of one of the parties, that there was, or should be, no contract, the court gave the other party contractual or statutory remedies, that could be regarded as a limitation or, an interference with, the right to freedom of thought, conscience and religion under Article 9 ECHR. ${ }^{119}$

In Hosanna-Tabor the SC was strongly influenced by historical incidents going back to the early 19th century. This weighed much more heavily than the societal interest protected by employment discrimination statutes. ${ }^{120}$ In Percy and Moore it was the modern context of statutory protection for employees that had led to the inclusion of Ministers as employees. ${ }^{121}$ In Hosanna-Tabor the SC made no reference to regional or international human rights. In Moore raised but dismissed the relevance of Article 9 ECHR on the facts. The CA's description of the attempted invocation of Article 9 as reflecting 'moral poverty' is striking. ${ }^{122}$

${ }^{113}$ Cf Starkman v Evans 198 F.3d 173 (5th Cir. 1999) (choirmaster's disability claim dismissed); Archdiocese of Washington v Moersen 925 A.2d 659 (Md. 2007), cert. denied, 128 SC 1217 (2008) (church organist did not qualify as a Minister); Tomic v Catholic Diocese of Peoria 442 F.3d 1036 (7th Cir. 2006) (music director could not bring age discrimination claim).

${ }^{114}$ See eg Snyder v Phelps, 131 SC 1207 (2011) (First Amendment shielded church members who picketed near the funeral of a military service member. The protest was against the political and moral conduct of the US and its citizens, including the Catholic church, as well as against homosexuality in the military); In Re Kirk Session of Sandown Free Presbyterian Church [2011] NIQB 26, [2011] NI 242 (restriction on church elders' freedom of expression to place advert in newspaper in opposition to gay pride march was a disproportionate interference with their freedom of expression).

${ }^{115}$ Evans and Hood, supra n 8, 104.

116 Ibid. at para 66. See also Singh v Bristol Sikh Temple Management Committee, EAT, Appeal No. UKEAT/0429/11/ZT, Westlaw No. 2012 WL 382724. The issue was whether a priest at a Sikh temple had been a worker within the meaning of the s 54(3)(b), National Minimum Wage Act 1998 . For arrangements between a church and its ministers to be taken as intended to have no legal effect there had to be religious beliefs contrary to the implication of a contract. The tribunal had not approached the matter in that way: there was no finding that a contractual relationship would be inconsistent with the relevant scripture or with T's practice and beliefs (see paras 32-9). The ET had found as a fact that there were different opinions in Sikhism on whether priests should have contracts.

${ }^{117}$ Per Arden LJ in New Testament Church of God v Stewart, supra n 93 at para 62.

118 See Singh, supra n 120 (there had been no such finding as regards the Bristol Gurdwara).

${ }_{119}$ Preston/Moore, CA, pr. 32, following Lawrence Collins LJ in Stewart, supra n 93, para. 66.

${ }^{120}$ See supra nn 19-20.

${ }^{121}$ See supra $\mathrm{n}$ 91. In the UK decisions on vicarious liability for members of religious communities, supra nn 104-105, there has been recognition that 'because the doctrine of vicarious liability is a legal construct based on policy its application has depended on the weight given to the various policy rationales in particular cases and to changes in circumstances and public perceptions over the generations.', per Davis LJ in JGE case, supra n 104, para 133.

${ }^{122}$ See supra n. 99. 
On the face of it, the decision of the ECtHR in Fernandez-Martinez looks as though it creates a similar legal vacuum to Hosanna-Tabor by appearing to move towards a similar ministerial exception. ${ }^{123}$ However, it is submitted that such an appearance is deceptive. The jurisprudence does not create such a vacuum. Rather there is a small black hole and even within it there is some matter in terms of applicable legal principles. There must be a balancing of the rights of religious organisations against the rights of individuals. ${ }^{124}$ Any degree of balancing of rights necessarily gives less protection to the interest of religious organisations than does a Ministerial exception. The decisions of the national courts must be reasoned and reasonable. A contractual acceptance of obligations of loyalty will be given weight. So too will the religious beliefs of a person who wishes to engage in teaching the morals or ethics of a particular religion. This is to preserve the right to religious freedom in its collective dimension. The ECtHR's role is limited to verifying that the fundamental principles of the internal legal order and the dignity of the individual have been maintained. Admittedly, it will not go further and examine the necessity and proportionality of a particular decision of non-renewal. However, the state must remain within its margin of appreciation and a 'fair balance' must be maintained between the various private interests. In Fernandez-Martinez the ECtHR went to great pains to explain how the decision in that case was distinguishable on the facts, rather than on principle, from the balancing approach taken in Obst and Schüth.

Would the presence of clear discrimination on ECHR grounds be relevant? If the Hosanna-Tabor school had been in Europe it is doubtful that the reasons for P's dismissal would have been seen as anything other than a pretext and would not have been protected by any ministerial immunity. If the school had been in the UK then the courts would have required the clearest of evidence to establish that the existence of a contract of employment between the Church and $\mathrm{P}$ was contrary to its tenets. Allowing $\mathrm{P}$ to bring disability discrimination proceedings would not have been regarded as a limitation of, or an interference with, the right to freedom of thought, conscience and religion of the religious organisation under Article 9 of the ECHR. In Fernandez-Martinez the ECtHR found that FM had not been discriminated against. What if there was a clearer allegation on the facts of discrimination covered by the ECHR? Case 51/2011 of the Spanish Constitutional Court ${ }^{125}$ concerned Ms Resurreción Galera, a practicing teacher of the Catholic religion in a state school, who married a divorcee in a civil ceremony. The Diocesan Bishop failed to renew her contract of employment. His agreement was necessary under he same agreement involved in the Fernandez-Martinez case. The Constitutional Court held that the failure to renew the employment contract due to her

\footnotetext{
${ }^{123}$ See S. Smet, 'Fernández Martínez v. Spain: Towards a 'Ministerial Exception’ for Europe?' Strasbourg Observers, 24 May (2012), Strasbourg Observers, available at: http://strasbourgobservers.com/ [last accessed 27 June 2012].

${ }^{124}$ See also Sindicatul 'Păstorul cel Bun'v. Romania, Application no 2330/09, Merits, 31 January 2012 (a relationship based on an employment contract could not be 'clericalised' to the point of being exempted from all rules of civil law. Hence, members of the clergy, and to an even greater extent lay employees of the Church, could not be excluded from the scope of protection of Article 11 ECHR by a refusal to register a trade union of church employees. In so far as the refusal had sought to prevent a disparity between the law and practice concerning the establishment of trade unions for Church employees, it had been aimed at protecting public order, which encompassed the freedom and autonomy of religious communities. However the ECtHR observed that the trade union's statutes specified that it intended to fully comply with and apply the provisions of the civil legislation and the ecclesiastical rules, including the Statute and canons of the Church. The union's demands had related exclusively to defending the economic, social and cultural rights and interests of salaried employees of the Church. Hence, recognition of the union would not have undermined the legitimacy of religious beliefs or the means used to express such beliefs. The criteria defining a 'pressing social need' were therefore not met). A panel of the Grand Chamber has accepted the request of the Romanian government to refer the case to the Grand Chamber.

${ }^{125}$ Available at: http://www.tribunalconstitucional.es/es/jurisprudencia/Paginas/Sentencia.aspx?cod=10117 [last accessed 17 June 2012]
} 
marital status violated the Spanish Constitution. It discriminated against her on grounds of her personal beliefs (Article 14 of the Constitution), interfered with her ideological freedom (Articled 16 of the Constitution) and interfered with her right to contract matrimony with full legal equality (Article 32 of the Constitution). The Constitutional Court stated that the fact that Ms Galera had contracted civil marriage to a divorced man (which was the only reason given by the Bishop of Almería to justify his decision) was unrelated with the carried out educational she carried out and did not affect her knowledge or teaching skills. That decision effectively reversed a 2007 decision of the Spanish Constitutional Court. ${ }^{126}$ What if the Constitutional Court had maintained its 2007 decision? The ECtHR might still have held, as long as the national courts had sought to balance the respective interests in the case, such a decision would not have been unreasonable. Maintaining freedom of religion in its collective dimension will require that some aspects of discrimination are compromised. As Moon has observed, the principle of religious neutrality, that the state should neither favour nor disfavour a particular religious belief system, is 'unworkable when applied to religious community beliefs that address the rights and interests of others in the community'. ${ }^{127}$ Male only priesthoods are the classic example. Gay marriages are a contemporary example.

However, the ECtHR's reference to verifying that the fundamental principles of domestic law and the dignity of the individual have not been compromised may hint at some limits. Courts may accept that they have no authority or competence to interpret religious texts, ${ }^{128}$ but they are more likely to assert that they have a particular institutional expertise ${ }^{129}$ with respect to issues of discrimination. ${ }^{130}$ The ECtHR is particularly alert to allegations of discrimination on grounds of race, sex and, increasingly, sexual orientation. ${ }^{131}$ It will require weighty reasons to justify such discrimination. Religious doctrines will have weight in the balance but they will have to be narrow, specific and 'strictly religious'. ${ }^{132}$ In Hosanna-Tabor it seemed clear that the given reason for a dismissal could be a pretext but the US courts will not look behind the reasons given. In Fernandez-Martinez and other cases the ECtHR has closely examined the situation to ensure that the reason given was solely based on 'strictly religious factors'. ${ }^{133}$

In Obst and Schïth the ECtHR referred to the positive obligations of states towards litigants in the area of employment law. Methodist Conference v Preston is also clearly the product of modern rule of law thinking about the need for the statutory protection of individuals from discrimination and unfairness. ${ }^{134}$ In practice it means that the Churches are subject to

\footnotetext{
${ }^{126}$ Case 38/2007.

${ }^{127}$ Moon, 'The Supreme Court of Canada's Attempt to Reconcile Freedom of Religion and Sexual Orientation Equality in the Public Schools' in Rayside andWilcox (eds), Faith, Politics And Sexual Diversity (2011), available at: http://ssrn.com/abstract=1866491 [last accessed 1 August 2012]. He also observes that '[t]he [Canadian Supreme] court's reluctance to repudiate the view that homosexuality is sinful rests, in part, on the view that religion is a deeply rooter part of the individual's identity that should be treated with equal respect', ibid. at 337. He is critical of that view.

${ }^{128}$ See Rivers, supra n 1; Edge, supra n 2.

${ }^{129}$ This has been the case under the UK's Human Rights Act 1998. See, for example, see Ghaidan v Mendoza [2004] UKHL 30, (2004) 2 AC 557 (discrimination on grounds of sexual orientation).

${ }^{130} R(E) v$ Governing Body of JFS \& Others [2009] UKSC 15, [2010] 2 AC 728 (the admissions policy of JFS (formerly the Jewish Free School), which refused to admit a child who was not recognised as Jewish by the Office of the Chief Rabbi (OCR) because the OCR did not recognise the mother's conversion, discriminated against him directly on grounds of ethnicity rather than of religion was therefore unlawful under the Race Relations Act 1976). See McCrudden, 'Multiculturalism, Freedom of Religion, Equality, and the British Constitution: The JFS Case Considered' (2011) 9 International Journal of Constitutional Law 200.

${ }^{131}$ See Schalk and Kopf v Austria (2011) 53 EHRR 20 at para 97.

${ }^{132}$ See text accompanying n 58 supra. See also Sandberg, 'The Right to Discriminate' (2011) 13 Ecclesiastical Law Journal 157.

133 Ibid.

${ }^{134}$ See text to supra n. 91 .
} 
modern day employment legislation. However, the force of religion still exerts a distinct pressure because religious doctrine will strongly factor into the equation in determining whether a particular dismissal is fair or discriminatory. The force of religion may render a dismissal fair which would otherwise be classified as unfair and non-discriminatory what would otherwise be discriminatory.

American constitutional jurisprudence has long been a classical first point of reference for human rights scholars. ${ }^{135}$ However, it is submitted that in terms of protecting religious autonomy of religious organisations the ministerial exception is rather a blunt legal doctrine. In some cases it operates to defend the indefensible. ECtHR and British jurisprudence offers more sophisticated, balanced and elegant mechanisms to protect such organisational autonomy in cases where it can be justified. Churches and religious organisations will have a better chance of defending their autonomy if there is an open and principled engagement with other legal principles that express important contemporary values. A ministerial exception makes religious support for anti-discrimination laws appear hypocritical. It is submitted that hiding in legal vacuums or black holes like the ministerial exception is a short-term and short-sighted strategy that religious organisations should resist.

${ }^{135}$ See Stavros, 'Freedom of Religion and Claims for Exemption from Generally Applicable, Neutral Laws: Lessons from Across the Pond?' [1997] European Human Rights Law Review 607. 